\title{
Lexical-semantic groups of the verbs of motion in structurally different languages (on the material of the Russian and the Tatar languages)
}

\author{
[Лексико-семантические группы глаголов движения \\ в разноструктурных языках (на материале русского и татарского \\ языков)]
}

\author{
Gelinya Kh. Gilazetdinova - Ruzilya R. Salakhova
}

DOI: $10.18355 /$ XL.2018.11.04.04

\begin{abstract}
The article is devoted to the study of the verbs of motion in Russian and Tatar. The verbs of vibrational and rotational motion are investigated. Lexico-semantic variants of the verbs are analyzed in the article; their equivalents are found out. Semantic similarities and differences are defined. Special derivative features of the verbs of motion in the compared languages are described. The importance of the research is determined by the practical output connected with the study of verbs in the context of bilingualism.
\end{abstract}

Key words: verbs of motion, oscillatory motion, rotational movement, Russian language, Tatar language

\begin{abstract}
Аннотация
Статья посвящена изучению глаголов движения в русском и татарском языках. Исследуются глаголы поступательного, колебательного, вращательного движения. Показаны лексико-семантические варианты анализируемых глаголов, выявлены их эквиваленты, определены сходства и различия семантики. Представлены словообразовательные особенности глаголов движения в сопоставляемых языках. Важность исследования определяется практическим выходом, связанным с изучением глаголов в условиях билингвизма.

Ключевые слова: глаголы движения, колебательное движение, вращательное движение, русский язык, татарский язык
\end{abstract}

\begin{abstract}
Введение
Как известно, лексико-семантические группы слов представляют собой своеобразные микросистемы языка на лексическом, грамматическом и словообразовательном уровнях. Изучение лексико-семантических групп и их лексическое описание, разработка типологии невозможно без обращения к сопоставительному анализу данных образований в разноструктурных языках. Предметом данного сопоставительного исследования являются разноструктурные русский и татарский языки. Актуальность данной темы определяется межкультурными барьерами при изучении глаголов движения в условиях билингвизма, возникающими, на наш взгляд, вследствие недостаточного сопоставительного анализа. При сравнении неродственных языков специфика каждого из них проявляется достаточно ярко. Особенно интересен в этом плане словообразовательный уровень, поскольку при его исследовании на поверхность выступает тот типовой признак, который лежит в основе наименования целых классов слов, отчетливее проступают системные связи и отношения, связывающие всю структуру языка.
\end{abstract}




\section{Методология}

В работе были использованы следующие методы: сопоставительный, структурно-функциональный, статистический и метод компонентного анализа.

Семантическая структура любого глагола - это комплекс семантических компонентов, сем, которые могут получать свое формальное выражение на одном из уровней языковой структуры. Наиболее часто в качестве таких параметров глагольного действия выступают: способ движения, направление движения, среда, расстояние, охватываемое действием, время и фазы его протекания, количество участников, интенсивность, способ действия и др. Каждый из названных параметров может иметь дальнейшее членение: например, способ действия (перемещение в пространстве, положение в пространстве и т.п.). В этом плане интересны исследования ученых Института семиотики Академии наук Республики Татарстан, которые занимаются разработкой лингвистической базы и созданием иерархической семантической модели глаголов татарского языка на базе WordNet (Galieva, Nevzorova, Suleymanov 2015; Galieva, Nevzorova 2016).

Глаголы движения с давних пор были предметом внимания многих лингвистов. Они исследовались в разных аспектах и на материале многих языков. Но в ранних трудах лингвистов о глаголах движения имелись лишь отдельные высказывания, которые служили иллюстрацией видового различия в процессе словообразования. Из истории изучения глаголов движения следует отметить, что среди ученых долго шли споры по определению единых критериев для выделения глаголов движения и перемещения. Одни исследователи полагают, что основным критерием для выделения их является кратность и некратность движения (В.А.Богородицкий, А.М. Пешковский, А.А. Шахматов), другие за основу принимают направленность движения (Г.П. Павский, Н.А. Аверьянова, Н. Сирбу), третья группа ученых считает, что основным критерием служит абстрактность или конкретность движения, обозначенные в основе глагола (А.Х. Востоков, 3.У. Блягоз). По нашему мнению, при изучении глаголов движения необходимы все три критерия, так как глаголы данного типа в разноструктурных языках мы исследуем в сравнительном аспекте.

Исследование лексико-семантических групп (ЛСГ) глаголов движения в разносистемных языках имеют важное теоретическое и практическое значение для разработки вопросов семантики, лексики, словообразования и стилистики, а также для практики лексикографической работы, методики преподавания языка в вузе и школе. Следует особо подчеркнуть значимость изучения ЛСГ глаголов движения в сопоставительном аспекте при дистанционном обучении языку (например, татарскому) на онлайн-курсах (Fatkullova, Zamaletdinov, Yusupova 2013; Gimaletdinova, Khalitova 2016).

Теоретическую основу нашей работы составляют положения и выводы, содержащиеся в трудах Р.С. Газизова (Gazizov, 1977), Р.А. Юсупова (Yusupov, 1980), А.А. Аминовой (Aminova, 1996), В.Б. Сувановой (Suvanova, 2006).

Цель статьи - выявление и системное описание лексико-семантических групп глаголов движения татарского и русского языков в сопоставительном аспекте.

Материалом исследования послужили одноязычные и двуязычные (русскотатарские и татарско-русские) словари. Дополнительным источником явились толковые словари русского и татарского языков. Примеры извлечены из Татарского национального корпуса «Туган тел» (Tatar National Corpus «Tugan Tel») и Национального корпуса русского языка (National corpus of the Russian language). Переводы татарских текстов осуществлены авторами статьи.

XLinguae, Volume 11, Issue 4, October 2018, ISSN 1337-8384, eISSN 2453-711X 
Считается, что лексико-семантическая группа глаголов движения состоит из трех основных классов: глаголы поступательного, колебательного и вращательного движения (Ibragimova, 1988; Galieva, Zamaletdinov, 2015: 33).

\section{Глаголы поступательного движения}

Основным признаком глаголов поступательного движения является направленность движения, состоящая из разных компонентов: движение по горизонтали и вертикали, вверх - вниз, внутрь - изнутри наружу, с пересечением границы пространства - без пересечения границы, от точки - к точке и т.д. На основе лексико-семантических признаков в татарском языке глаголы поступательного движения подразделяются на две подгруппы:

1. Глаголы, обозначающие направление движения: бару - идти, керу войти, төшү - спускаться.

2. Глаголы, обозначающие способ движения: атлау - шагать, йөзY - плавать, йөгерY - бежать, агу - течь (Tatarskaya grammatika 1997: 74).

Глаголы, обозначающие направление движения, включают группу глаголов, фиксирующих векторные характеристики движения по вертикали: а) вверх: күтәрелү - подниматься, менү - взбираться, подниматься, залезать (вверх), взбираться, үрләү - подниматься вверх, набирать высоту; б) вниз: төшү спускаться, опускаться, түбәнәю - снизиться; и по горизонтали: а) вовнутрь: керY - входить, въезжать; б) изнутри: чылу - выходить, выезжать; в) к субъекту или объекту: якынаю - приблизиться, кил $Y$ - прийти; г) от субъекта или объекта: китү - уходить, ерагаю - удаляться, чиген $Y$ - пятиться (Gilazetdinova, Salakhova, 2016: 50-51).

Глаголы, обозначающие способы движения, в отличие от глаголов направленного движения, могут приобрести признак направленности в определенном контексте. Характер движения в них уточняется с точки зрения среды, способа, темпа, образной характеристики. В группе глаголов, обозначающих среду движения, можно выделить следующие виды: а) глаголы со значением движения по твердой поверхности: атлау (шагать), Үрмәләу (ползти), шуу - кататься (на коньках, санках, лыжах).

Тапталган сукмактан бер адым читкә атласац, бил тиңентен батасың да китәсең (Г. Апсалямов). Чуть шагнешь в сторону от протоптанной тропинки, обязательно провалишься по пояс в снег.

Значение передвижения по земле в татарском языке не дифференцировано в зависимости от способов передвижения (пешком или на транспорте), оно выражается одним словом - бару (передвигаться). Для выражения передвижения на транспорте используется дополнительные лексические средства, обозначающие конкретный вид транспорта: машина белән бару (ехать на машине), поезд белән бару (ехать на поезде). Следовательно, словом, которое однозначно выражало бы значение ехать, татарский язык не располагает. В русском языке способ передвижения - пешком или на транспорте - лексически дифференцирован: для этого употребляются соответственно глаголы $и д т и$ и ехать.

б) глаголы со значением движения по воздуху: очу - летать, лететь.

Парлашып ж⿻ырлап куялар, йөрәкне телеп-телеп, күлләрдән диңзез буена очачак кошлар кебек (Ш. Камал). То запевают они, навевая острую грусть, как птицы которые должны улететь из наших озер к морям.

В русском языке передвижение человека по воздуху при помощи какой-либо техники обозначается, как и процесс передвижения птиц, глаголом лететь, при этом вовсе необязательно упоминание средства передвижения. Например, лететь в Москву. Для татарского языка несвойственно обозначать передвижение человека по воздуху словом очу (лететь), которое 
употребляется лишь по отношению к птицам и летательным аппаратам. Передвижение же человека по воздуху выражает глагол бару, то есть передвигаться с указанием летательной техники. Следовательно, значение вышеуказанного словосочетания было бы неправильно перевести на татарский язык как Мәскәугә очу, а следует выразить как Мәскәүгә самолет белән бару (Лететь в Москву на самолете).

в) глаголы со значением движения в жидкой среде: йөзY-nлыть, плавать, агу - течь, протекать, литься. Агыйдел тын гына ага да ага (М. Амир). Река Белая спокойно течет себе и течет.

В татарском языке словом йөзY, соответствующим основному значению русскому глаголу пльтьь, обозначается лишь процесс передвижения человека по воде без специальной техники, а также передвижение рыб и плавающих животных. Для носителя русского языка передвижение человека по воде независимо от того, при помощи плавательной техники он передвигается или без нее, естественно было передать глаголом плыть. Соответственно этому, если по-русски можно сказать Я плыл из Казани на теплоходе, то по-татарски следует сказать Мин Казаннан теплоход белән бардым (не йөздем - плыл) (Salakhova, Sibgaeva, 2014: 326).

В русском языке глаголы поступательного движения являются устойчивой структурно-семантической группой глаголов несовершенного вида, объединяющихся в пары слов с общим корнем (кроме разнокорневых в паре идти - ходить). Эти слова противопоставлены другу другу по значениям однонаправленности - неоднонаправленности движения, а также по кратности - некратности. Соотносительные пары глаголов движения следующие: бежать - бегать, брести - бродить, везти - возить, вести - водить, гнать гонять, гнаться - гоняться, ехать - ездить, идти - ходить, катить катать, катиться - кататься, лезть - лазить, лететь - летать, плыть плавать, ползти - ползать, тащить - таскать, тащиться - таскаться, нести - нестись (Russkaya grammatika 1980: 590-591).

От глаголов однонаправленного движения, во-первых, с помощью приставки по- образуются глаголы совершенного вида начинательного значения: бежать - побежать, ехать - поехать, идти - пойти и др.

Он пошёл быстрее, и мне пришлось бежать за ним в своих красных босоножках (А.Чернов). Сердие его бешено колотилось в груди и очень захотелось побежать (Д. Суслин).

Во-вторых, при помощи приставок вbl-, до-, nepe-, om- образуются глаголы пространственного значения типа выбежать, добежать, перебежать, отбежать. Указанные приставки образуют и видовые пары. Например, перебежать - перебегать, добежать - добегать, отбежать - отбегать.

Там без кониа пытались перебежать дорогу большие и лохматые собаки (С. Самаров). Нам пришлось перебегать из подъезда в подъезд, из дома в дом (М. Серова).

От глаголов разнонаправленного движения также образуются приставочные глаголы совершенного вида с различными оттенками значения, например, ограниченное во времени действие (походить) или результат действия (износить).

Теперь попробуй походить по комнате (В. Кольцов). Странно и обидно, когда вещь покупают не для того, чтобы износить, а для того, чтобы сберечь (Д. Бутрин).

В татарском же языке глаголы одного и того же лексического значения не подразделяются на виды по признаку совершенности и несовершенности. Однако отсутствие совершенного и несовершенного вида в татарском языке не является препятствием для образования разнообразных значений глаголов

XLinguae, Volume 11, Issue 4, October 2018, ISSN 1337-8384, eISSN 2453-711X 
поступательного движения. Если в русском языке такую функцию выполняют приставки, в татарском же языке эту роль выполняют модифицирующие глаголы. В роли функционально модифицирующих глаголов выступают полнозначные глаголы, среди которых огромное множество глаголов поступательного движения. Рассмотрим некоторые из них:

1) деепричастие + модифицирущий глагол керY выражает действие, направленное вовнутрь, иногда с оттенком неожиданности: кайтыл керу (вернуться), килеп керу (войти).

Өйгә килеп кердем, анда мине әни каршылады (А. Еники). Зашел в дом, там меня встретила мама;

2) деепричастие + модифицирущий глагол китү выражает действие, совершающееся с удалением в каком-нибудь направлении от исходного пункта, или начало действия: кайтыл китү (пойти (домой), йөгереп китү (побежать), чаптырып китү (ускакать).

Алмаев язып бетерде дә урыныннан торып кабинет буйлап йөреп китте (Г. Ахунов). Дописав, Алмаев встал иначал ходить по кабинету;

3) деепричастие + модифицирущий глагол төшү выражает внезапное действие: килеп төшү (прибыть).

Сибгат карт тагын шушы приискалар һәм үзенең кайларда йөргәнен сөйләп барганга күрә, без шахтага килеп төшкәнебезне сизми дә калдык (М. Гафури). По пути на шахту старик Сибгат все рассказывал об этих приисках и о тех местах, где он побывал, поэтому мы и не заметели, как прибыли к шахте.

4) деепричастие + модифицирущий глагол чыгу выражает действие совершающееся в определенных пространственных пределах: йөреп чыгу, әйләнеп чыгу (обойти) и действие направленное через какое-нибудь пространство, предмет: йөзеn чыгу (переплыть), атлап чыгу (перешагнуть), сикереп чысу ( перепрыгнуть).

Якуб бушап калган бакчаларны йөреп чыкты да таш жстйгән юл буйлап китеп барды (И. Гази). Якуб обошел опустошенные огороды и ушел по дороге, вымощенной камнями.

Таким образом, в русском языке пространственные значения оформляются с помощью префиксов и конфиксов, присоединяемых к непроизводным глаголам движения. Что касается татарского языка, то для передачи пространственной семантики существует небольшая, но функционально важная группа глаголов, лексическая основа которых выражает направление в пространстве - керу (войти), чыгу (выйти).

Как видно из примеров, в татарском языке в качестве модифицирующих глаголов выступают глаголы поступательного движения. По нашим подсчетам, число таких глаголов достигает восьми. Это следующие глаголы: йөрY (ходить), керY (войти), чысу (выйти), китү (уходить), килү (приходить), төшү (спускаться), узу, $y^{m} Y$ (проходить). Необходимо уточнить, что в качестве их лексических основ могут выступать не только глаголы движения, но и глаголы из других семантических групп. Так, словообразующий тип «деепричастие + модифицирующий глагол бару» выражает: 1) нарастание, развитие действия, усиление действия: яхшыланып бару (улучшаться); 2) действие, развивающиееся в направлении своего конца, предела: бетеп бару (кончаться); 3) регулярно совершающееся действие: укып бару (читать регулярно) и т.д. (Ganiev, 2015: 132-133). 


\section{Глаголы колебательного движения}

Глаголы колебательного движения - один из подклассов глаголов способов движения. Это глаголы обозначают движение на месте или в пределах очень ограниченного, замкнутого пространства. Колебательное движение складывается из отдельных квантов, когда квантом колебания является движение из одной крайней точки движения в другую, где его направление меняется на противоположное (Ibragimova, 1982: 72).

По мнению Л.М. Васильева, в русском языке глаголы движения имеют следующие подклассы: глаголы поступательного и непоступательного движения, глаголы вращательного движения. Под термином «непоступательное движение» лингвист рассматривает колебательное движение, причем типовая семантика глаголов колебательного движения описывается так: «мерно двигаться в разных направлениях» (Vasilyev, 2002: 73).

Глаголы собственно колебательного движения (качания) обозначают независимое движение, которое состоит в цикличном отклонении тела субъекта от центра равновесия то в одну, то в другую сторону. Данную группу образуют возвратные соотносительные глаголы типа колебаться колебнуться, качаться - качнуться, шататься - шатнуться, кольхаться кольхнуться, болтаться - болтнуться, мотаться - мотнуться.

Глаголы колебательного движения русского языка можно разделить на два вида. Во-первых, это глаголы беспорядочного движения: шевелиться, трогаться, метаться, рваться.

Ему казалось, если он не будет шевелиться, неведомые обитатели заметят его, так и будут шуршать рядом (М. Тырин).

Во-вторых, это глаголы однообразного движения, которые, в свою очередь, делятся на две подгруппы:

1) ритмичные частые движения: трястись, дрожать, вздрагивать, вибрировать, сотрясаться, дрыгать, мериать и др.

Остальные решили куда-нибудь зайти, чтобы не дрожать на ветру, открыли первую попавшуюся дверь и усльшали "Катюшу" (В. Аксенов).

2) неритмичные движения из стороны в сторону или сверху вниз с непостоянной амплитудой колебания: качаться, шататься, реять, раскачиваться, размахиваться и т.д.

Между тучами и морем гордо реет Буревестник, черной молнии подобный (М.Горький); Нескладно размахиваясь, он сбивал, а не срезал траву (В. Быков).

Таким образом, в русском языке глаголы колебательного движения несовершенного и совершенного вида противопоставляются по семантическим признакам: «из стороны в сторону/в одну сторону», «многоактно/одноактно», «в пределах пространства, ограниченного амплитудой движений/в пределах пространства одной фазы движения», «длительно/одномоментно». Глагол качаться является ядерным в данной группе и обладает широкой семантической сочетаемостью. Ср.: Стрела крана с висящими на ней операторами качалась вверх-вниз (В. Аксенов).

В татарском языке глаголы колебательного движения, как и другие подклассы глаголов движения, к сожалению, не нашли необходимое отражение в монографических трудах. По нашим данным, количественный состав глаголов колебательного движения в татарском языке чуть превышает одного десятка (всего 13), в то время как в русском языке мы насчитали более двух десятков аналогичных глаголов (24). В татарском языке к глаголам колебательного движения можно отнести следующие: селкен калтырау - дрожать, селтәу - махать, селкY - отряхивать, жсилпY - махать,

XLinguae, Volume 11, Issue 4, October 2018, ISSN 1337-8384, eISSN 2453-711X 
веять, кыймылдау - шевелиться, кагу - трясти, махать, дерелдәY - дрожать, тетрәү - содрогать, тирбәлү - колыхаться, тирбәнү - колебаться, атыну качаться, чайкалу - шататься, жсилфердәY - реять, трепетать. Рассмотрим некоторые из них.

СелкенY - шевелиться, приходить в движение под действием чего-либо, не совершая при этом поступательного движения. Для глагола селкену повторяемость движений и количество итераций несущественны: это может быть, как единичное (однократное), так и повторяющееся движение.

Ахырда бөтенләй терелгән, башы селкенмәс булган (Г. Абсалямов). В конце кониов он поправился, голова перестала трястись.

Движения, выражаемые этим глаголом, не обязательно регулярные, они могут быть однократными или повторяющимися, беспорядочными; а в ситуациях, когда описывается движение типа маятника, имеется в виду в первую очередь само наличие движения, но не его характеристика как колебательное (Galieva, Zamaletdinov, 2015: 34).

Специализированный глагол качания атыну - «качаться, совершать колебательные движения из стороны в сторону по типу маятника», когда движения обязательно регулярные и повторяющиеся (циклические, по определенному ритму). Образован от основы ату (бросать) путем присоединения аффикса рефлексива -ьлн.

Яиьләр таган атынган, көнозын жсырлап-биеп күщел ачу гадәте булган (Ф. Яруллин). Молодежь качалась на качелях, был обычай цельй день развлекаться с песнями и танцуами.

ЖилфердәY - «развеваться, колыхаться в воздухе от ветра или движения». Глагол образован от звукоподражательного сочетания жсилфер-жсилфер (звуки, издаваемые при колыхании ветром развевающегося предмета, чаще всего из ткани). Используется по отношению к ткани, полотнищу и другим подобным мягким и гибким объектам, то есть сочетаемость ограничена объектами, которые могут развеваться при ветре или движении, меняя форму.

Атлар кузгалды, һәр ике яктан да яульклар жсилферди башлады (Г. Баширов). Лошади тронулись, с обеих сторон начали развеваться платки.

Как уже отмечалось, глагол жсилфердәу предполагает довольно интенсивные движения развевающегося объекта, если нужно подчеркнуть плавность движений (Tatarskaya grammatika, 1998: 113). При тех же сочетаниях используется глагол чайкалу.

Чайкалу - «совершать плавные колебательные движения в воде или воздухе из стороны в сторону и/или сверху вниз». Образовано от глагола чайкау «полоскать в воде, покачать головой или руками» присоединением аффикса пассива. Движения, описываемые глаголом чайкалу - плавные, не очень быстрые. В значительной части контекстов присутствует вода или описывается движение на воде.

Кайчагында исә икәүләп, билләреннән тотынышыл һәм көй уңзаена чайкала биреп, жсъьрлап жсибәрәләр (Ш. Камал). Иногда они становились рядом и запевали вдвоем, обнявиись и покачиваясь в такт мелодии.

Глагол тирбәлү/тирбәнү/тибрәлү/тибрәнү обозначает повторяющиеся колебательные движения с большим количеством итераций.

Ә тулган айга жситез-тере генә бер йолдыз ияргән... Ул да тибрәнотибрәнә... тибрәнә-тибрәнә... (М. Амир). А за большой круглой луной увязалась одна-единственная иустрая звездочка... Она как-то странно дрожст ... Все дрожит, дрожит ...

Из всех татарских глаголов движения именно этот выражает в наибольшей степени упорядоченность, ритмичность колебательного движения и большое количество итераций. 
Таким образом, и в русском и в татарском языке имеется значительный набор средств для выражения разных типов колебательного движения. Русские глаголы собственно колебательного движения дифференцируются на основе видовой оппозиции. В татарском языке глаголы собственно колебательного движения дифференцируются на основе семантического признака.

Формирование универсальных критериев категоризации глаголов колебательного движения и сопоставительное исследование их семантики представляются чрезвычайно важными как для формирования полной картины отражения в языке многомерного концепта «движение», так и для выявления национальной специфики этого отражения.

\section{Глаголы вращательного действия}

Глаголы вращения - одна из особенных групп глаголов способа движения. Это небольшая подгруппа глаголов, семантика которых связана с описанием движения по круговой траектории. В русском языке, например, для описания ситуаций вращения используется восемь глаголов, ср.:

Крутиться - контролируемое или управляемое вращение тел, имеющих собственную (внутреннюю) ось, число оборотов не важно.

Метрах в пятидесяти от них лежит замерший к верху колёсами мотоцикл: они продолжают крутиться в воздухе (В. Гроссман).

Вертеться - неконтролируемое и неупорядоченное (возможно - в разные стороны) вращение субъекта вокруг собственной оси.

Пусть всегда в вашей жизни сияет солнце научных побед и стрелка компаса вертится с бешеной скоростью - вам, геологам, хорошо известно, что это значит! (А. Луковкина).

Вращаться - равномерное круговое движение с большим числом оборотов вокруг собственной или внешней оси.

Когда колёса парохода начали вращаться, она вышла на боковую палубу, чтобы в последний раз взглянуть на родные лица (С. Кулидж).

Кружсть - круговые движения над находящимся внизу на большом расстоянии ориентиром:

На берегу палили пушки, над головами, сбрасывая парашютистов, кружили самолёть (В. Аксенов);

Кружситься - поступательное движение, сопровождаемое вращательным: Крупные снежинки кружились на ветру, будто гусинье перья из огромной распоротой подушки (Л. Погребин).

Виться - движение по спиральной траектории, рефлексивное расширение длинных гибких предметов:

Две тысячи километров тянется, вьется центральная колымская трасса шоссе среди сопок, ущелий, столбики, рельсы, мость (М.Шаламов).

Катиться - вращение вокруг внутренней оси, сопровождаемое однонаправленным перемещением в тесном контакте с плоскостью:

И пусть шёл дождь и даже снег, ничто не могло помешать мячу катиться, а детям - бегать за ним (Б. Бланше).

Kamambcя - разнонаправленные неполные повороты в тесном контакте с плоскостью, без перемещения:

Когда позволял ландшафт, машины начинали кататься вокруг жертвы, медленно сжимая кольцо окружения (В. Шалыгин).

Как видно из примеров, глаголы вращательного движения, то приближаясь по характеру обозначаемого ими перемещения к классу глаголов колебательного движения и контактируя с полем интенсивности через

XLinguae, Volume 11, Issue 4, October 2018, ISSN 1337-8384, eISSN 2453-711X 
признаки «быстро» и «медленно», представляют бесконечное возвращение к началу пути (к исходной точке) и передают неспособность (а иногда невозможность) достичь цели.

Ситуация вращения в татарском языке описываются следующими пятью глаголами: дйләнү - вертеться, вращаться, кружить, кружиться, урау намотать, окружать, объехать, бөтерелY - вихриться, кружиться, юлить, бору - вертеть, завинтить, крутить, тәгәрәY - катиться, перекатиться. Рассмотрим некоторые из них.

Глагол yрау (мотать, наматывать) означает вращение вокруг собственной или внешней оси в одной плоскости с ориентиром, движение по спиральной траектории, закручивание длинных гибких объектов.

Беренче пар ат ишегалдына шаулап килеп керде һәм ишегалдын уратып,

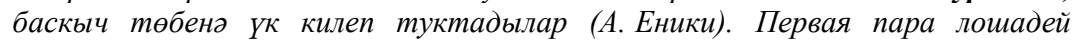
влетела во двор, на всем скаку описала круг и как вкопанная стала у самих ступеней крыльца.

БөтерелY (вихриться, кружиться) - очень быстрое неконтролируемое, неравномерное вращение вокруг внутренней оси, напоминающее вихрь или воронку.

Һәркемнең Үз хезмәте: һавада, дйлән-бәйлән уйнап, яфраклар бөтерелә (Г. Баширов). У каждого свои дела: в воздухе, таниуя в хороводе, кружатся листья.

Tәгәрәу (катиться) - однонаправленное вращение вокруг собственной оси, сопровождаемое передвижением по плоскости, с различимыми оборотами вращения; вращение вокруг собственной оси. Алма тәгәрәгән жсирдә алма исе калмый булмас (поговорка). Там, где прокатилось яблоко, не может не остаться его запах.

Әйләнү (вертеться, вращаться, кружить, кружиться) - равномерное целенаправленное и контролируемое, достаточно медленное вращение вокруг внешнего ориентира, на расстоянии от него, в том числе на расстоянии по вертикальной оси (т.е. над ним), полные и неполные обороты.

Әйләндем-тугландым да, эщ белән двәрә килгән хужсаларның күзләреннән бераз югалып торыйм дип, тагын больнга чыгып ктәрга булдым (М. Амир). Повертевшись по двору, я не смог придумать ничего лучшего, как скрыться на время с глаз озабоченных хозяек.

Показательно, что ядерным в группе глаголов колебательного движения является глагол әйлән $Y$, который обладает наиболее широкой семантической сочетаемостью: 1) вертеться, вращаться, кружить, кружиться; 2) поворачиваться, повернуться, обернуться, оборачиваться; 3) переворачиваться, перевернуться, ворочаться; 4) обходить, объезжать (Tatarsko- russkiy slovar'1995).

Кроме того, в татарском языке имеются и аналитические формы данного глаголы с разнообразными значениями: дйләнеп кайтырга - вернуться обратно, әйләнеп китәргә - завертеться, әйләнеп чыгарга - обойти кругом.

В русском языке, как и во многих других языках, глаголами вращения являются предикаты, описывающие длительное (многократное) движение со множествами оборотов. В татарском языке большинство глаголов вращения имеют именно подобное значение, однако есть и глаголы однакратного вращения. Например, глагол бору: колакнь бору (дернуть за уши). Хотя аналитические формы данного глагола, как и у всех глаголов вращения в татарском языке, весьма многообразны: борып алырга (отвертеть), борып кертергә (ввинтить), борып куярга (закрутить), борып чыгарырга (вывинтить), борып жсибәрергә (повернуть) (Tatarsko- russkiy slovar’1995: 80). 


\section{Заключение}

Семантическая структура глаголов движения татарского языка в большей части значений совпадает с аналогичной структурой русского языка. Указание на перемещение субъекта в пространстве между двумя точками как по горизонтали, так и по вертикали является обязательным для обоих языков и представлено антонимичными средствами типа керY (входить, въезжать), килеп керу (войти), кайтыл керу (вернуться), барып керу (зайти) и чыгу (выходить, выезжать), кереп чыгу (заскочить), альлn чысу (вывести), атлап чысу (перешагнуть), йөзеn чысу (переплыть), сикереп чыгу (перепрыгнуть); киту (уходить, уехать, отъехать, выехать) и килY (приехать, приходить, подъехать) и т.п. (Tatarsko-russkiy slovar'1995).

Необходимо отметить, что существует и сложные взаимоотношения между глаголами изучаемых языков. Например, двум татарским глаголам движения соответствует один русский глагол: тат. бару, кайту - рус. ходить; или двум русским глаголам соответствует в татарском языке один глагол: рус. $u д т и ~ u$ ехать - тат. бару. Характерно, что в «Толковом словаре татарского языка» приводится четырнадцать оттенков значений глагола бару, и шесть оттенков значений глагола кайту. Например, бару 1) идти, пойти, поехать; 2) идти, продолжаться (укулар майга кадәр барды - учеба продолжалась до мая); 3) идти, протекать, проходить (прочесс ничек бара? - как проходит прочесс?); 4) утверждать, говорить (син күрмәдем дип барасың инде - ты утверждаешь, что не видел); 5) выйти, выходить (кияүгә бару - выйти замуж); 6) подходить, быть к лицу (бу күлмәк сиңза бара - это платье тебе подходит); 7) приближаться к определенному возрасту (жситмешенче яме белән бара ему(ей) идет седьмой десяток); 8) в определенное время на сцене постановка спектакля или демонстрация на экране фильма (телевизорда кызыкль фильм бара - по телевизору идет интересны фильм); 9) усвояемость пищи организмом (аш тамагына бармый - суп не лезет в горло) и др. (Tolkovyi slovar' tatarskogo yazyka 2015: 65). «Толковый словарь руского языка» под ред. С.И. Ожегова и Н.Д. Шведовой у глагола ходить регистрирует семь оттенков значений: 1. То же, что идти. 2. Одеваться во что-нибудь, носить. 3. Быть с кем-нибудь, исполнять какие-нибудь обязанности, находиться в каком-нибудь состоянии (разг.). 4. Заботиться о ком-нибудь, ухаживать (разг.) и др. (Tolkovyi slovar' russkogo yazyka 2003: 865).

Различие в структурных характеристиках глаголов движения обусловлены типологическими особенностями сопоставляемых языков. Так, в русском языке глаголы движения образуются при помощи различных префиксов типа в-, $6 b l-$, om-, y-, nод-, nри- и др. Вполне естественно, что один и тот же «смысл» может быть передан разноуровневыми формальными средствами как в самом языке, так и в сравниваемых разноструктурных языках. Например, значение «движение вокруг точки» в русском языке выражается глаголами с префиксом об-: объехать, облетать, обползать, а в татарском языке - лексемами әйләнү

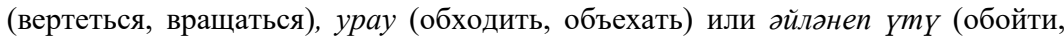
объехать), ypan yзу (обходить, объежать). Значение возвратного действия составляет основу русских глаголов вернуться и возвращаться. В татарском языке для такой цели существует глагол кайту, функционирующий как в самостоятельном употреблении - кайту (вернуться), так и в составе производной конструкции - oчыn кайту (прилететь), барып кайту (съездить).

Важно отметить, что составные глаголы в русском языке отсутствуют, а в татарском языке они очень распространены. Как видно из примеров, составные глаголы в татарском языке состоят из комбинации деепричастия на $-n$ или на $-a-\partial$, -bĭ/-u с рядом модифицирующих глаголов. Причем роль

XLinguae, Volume 11, Issue 4, October 2018, ISSN 1337-8384, eISSN 2453-711X 
модифицирующих глаголов очень часто выполняют глаголы движения типа йөрY (ходить), керY (войти), китY (уходить), килу (приходить), төшү (спускаться), узу (проходить).

\section{Выводы}

Глаголы движения в сопоставляемых языках, будучи универсальной категорией, являются одной из значимых лексико-семантических групп глаголов, передающих картину реального мира, так как движение - это форма существования материи. Следует отметить, что в обоих языках по объему глаголы движения составляют наибольшие группы. Это объясняется тем, что данные глаголы весьма употребительны в речи и передают важные процессы действительности, связанные с философскими категориями времени и пространства.

Сравнительно-сопоставительный анализ групп глаголов движения в изучаемых языках позволил выявить их специфические структурносемантические особенности. Так, с точки зрения структуры в татарском языке функционируют простые и составные глагольные единицы для обозначения движения, в то время как в русском языке - преимущественно простые, образованные префиксальным способом. В то же время отмечается несовпадение в семантике изучаемых глаголов в неродственных языках (ср. pус. ходить - тат. бару). Часто многокомпонентность семантической структуры сопоставляемых глагольных единиц не дает возможность свести ее к общему идентификатору.

Результаты данного исследования могут быть полезными для раскрытия механизма лексико-семантической трансференции, что позволяет наметить определенные подходы, которые следует учитывать при разработке и совершенствовании методики преподавания татарского языка в русскоязычной аудитории и, наоборот, русского языка в татароязычной аудитории. В частности, при изучении глаголов необходимо широко использовать элементы сопоставления лексико-семантических групп глагольных единиц данных языков с учетом их универсальных и нацональных особенностей.

\section{Благодарности}

Работа выполнена за счет средств субсидии, выделенной в рамках государственной поддержки Казанского (Приволжского) федерального университета в целях повышения его конкурентоспособности среди ведущих мировых научно-образовательных центров.

\section{Bibliographic references}

AMINOVA, A.A. 1996. Osobennosti semanticheskogo strukturirovaniya glagolnogo deistviya v russkom i tatarskom glagolakh // Modeli natsionalnykh yazykov. Kazan: Fen. Vyp. 4, pp. 6-12.

VASILYEV, L.M. 2002. Sistemnyi semanticheskiy slovar' russkogo yazyka. Vyp.3. Predikaty dvizheniya. Ufa. Izd-vo Bashkirskogo un-ta. ISBN 5-7477-0607-1

GAZIZOV, R.S. 1977. Sopostavitel'naya grammatika tatarskogo i russkogo yazykov. Kazan': Tatknigoizdat.

GALIEVA, A.M. - ZAMALETDINOV, R.R. 2015. Sposoby vyrazheniya mul'tisubyektnosti $\mathrm{v}$ tatarskom yazyk'e: grammaticheskiye i semanticheskiye aspekty// Filologia i kultura (Philology and Culture). № 3 (41). Kazan, pp. 32-38. ISSN 2074-0239 
GALIEVA, A. - NEVZOROVA, O. - SULEYMANOV, D. 2015. Corpus based Tatar Lexicography: Verbs in TatWordnet. In: Procedia-Social and Behavioral Sciences, 198, pp. 132-139. ISSN 1877-0428

GALIEVA, A. - NEVZOROVA, O. 2016. Semantic Annotation of Verbs for the Tatar Corpus. In: Proceedings of the XVII EURALEX International Congress: Lexicography and Linguistic Diversity. 6-10 September, 2016. Tbilisi, Ivane Javakhishvili Tbilisi State University, pp. 340-347. ISBN 978-9941-13-542-2

GANIEV, F. A. 2015. Funktsional'naya grammatika tatarskogo yazyka. Kazan.

ISBN 987-5-906701-56-5

GILAZETDINOVA, G.KH. - SALAKHOVA, R.R. 2016. Semanticheskiye osobennosti glagolov postupatel'nogo dvizheniya v tatarskom yazyk'e. In: Filologia i kultura (Philology and Culture). № 1 (43). Kazan, pp. 48-52. ISSN 2074-0239

GIMALETDIBOVA, G. - KHALITOVA, L. 2016. Self-paced learning: Investigating an online Tatar language course. In: XLinguae Journal, Volum 9, Issue 3, pp. 81-92. ISSN 1337-8384

IBRAGIMOVA, V.L. 1982. Semanticheskiye klassy glagolov kol'ebatel'nogo i vrashchatel'nogo dvizheniya v russkom yazyk'e // Issledovaniya po semantik'e. Ufa: Izd-vo Bashkirskogo un-ta, pp. 66-73.

IBRAGIMOVA , V.L. 1988. Semantika russkogo glagola (leksika dvizheniya): Uchebnoye posobiye. Ufa: Izd-vo Bashkirskogo un-ta.1988.

National corpus of the Russian language URL:// http://www.ruscorpora.ru/ (data obrashcheniya 20.05.2017).

OZHEGOV S.I. - SHVEDOVA N.YU. 1999. Tolkovyi slovar' russkogo yazyka: 80 tysiach slov i frazeologocheskikh vyrazheniy. M. Azbukovnik. 944 pp. ISBN 589285-003-X

RUSSKAYA grammatika 1980. M.: Izd-vo Nauka, T.1.

RUSSKO- TATARSKIY slovar' 1991. Pod red. F.A. Ganieva. M.: Russkiy yazyk. ISBN 5 200-01112-4

RUSSKO-TATARSKIY uchebnyi slovar' glagol'nogo upravl'eniya 2013. Kazan. Tatarskoye knizhnoye izd-vo. ISBN 978-5-298-02402-0

SALAKHOVA, R.R. - SIBGAEVA, F.R. 2014. Cross-linguistic differences as a type of lexical difficulties in Russian-Tatar translations. In: Journal of Language and Literature, Baku. Vol. 5, No. 4, pp. 325-328. ISSN 20780303

SALAKHOVA, R.R., 2015. Onomatopoetucheskaya l'eksika v tatarskom yazyk'e I sposoby yeyo perevoda na russkiy yazyk (na material'e romana A.Absal'amova «B'elyie cv'ety»). In: Filologicheskiye nauki: voprosy teorii ipraktiki. Tambov: Gramota. № 10(52). Ch.1,pp.159-162. ISSN 1997-2911

SUVANOVA, V. B. 2006. L'eksiko-semanticheskaya gruppa glagolov dvizheniya v tuvinskom yazyk'e (v sopostavitel'nom asp'ekt'e). Avtoref. diss.... kand. filol. nauk. Novosibirsk.

TATARSKAYA grammatika (na tatarskom yazyk'e): v 3-kh t. 1998. Kazan. Tatarskoye knizhnoye izd-vo. T. I. ISBN 5-85840-297-6

TATARSKAYA grammatika: v 3-kh tt. 1997. Kazan. Tatarskoye knizhnoye izd-vo.

T. II. Morfologiya. ISBN 5-298-00875-5

TATAR National Corpus «Tugan Tel». Available online: http://webcorpora.net/TatarCorpus/search/index.php?interface_language=ru (data obrashcheniya: 05.06.2017).

TATARSKO-RUSSKIY slovar'1995. Kazan. Tatarskoye knizhnoye izd-vo. ISBN 4602020000-086

TOLKOVYI slovar' tatarskogo yazyka 2015. T. I. Kazan. Institut yazyka, literatury i iskusstva im. G. Ibragimova. ISBN 978-93091-189-3

TOLKOVYi slovar' tatarskogo yazyka: v 3-kh t. 1979. Kazan. Tatarskoye knizhnoye izd-vo. T. II. ISBN 70105-034

XLinguae, Volume 11, Issue 4, October 2018, ISSN 1337-8384, eISSN 2453-711X 
TOLKOVYY slovar' tatarskogo yazyka: v 3-kh t. 1981. Kazan. Tatarskoye knizhnoye izd-vo. T. III. 832 p. ISBN 70105-089

FATKULLOVA, K.S. - ZAMALETDINOV, R.R. - YUSUPOVA, A.Sh. 2013. Information-communicative Devices for Tatar Language Teaching. In: World Appled Sciences Journal, vol.26, n.1, pp.103-107. ISSN 1818- 4952

YUSUPOV R.A. 1980. Leksiko-frazeologicheskiye sredstva russkogo i tatarskogo yazykov. Kazan, Tatarskoye knizhnoye izd-vo.

Words: 4863

Characters: 38822 (21,57 standard pages)

Prof. Gelinya Kh. Gilazetdinova, $\mathrm{PhD}$.

Department of General Linguistics and Turcology

Kazan Federal University

18 Kremlyovskaya St., 420008 Kazan

Republic of Tatarstan

Russia

ggilaz@mail.ru

Assoc. Prof. Ruzilya R. Salakhova, Phd.

Department of General Linguistics and Turcology

Kazan Federal University

18 Kremlyovskaya St., 420008 Kazan

Republic of Tatarstan

Russia

ruzilya5@mail.ru 